\title{
Global Impact of Mosquito Biodiversity, Human Vector-Borne Diseases and Environmental Change
}

\author{
Sylvie Manguin ${ }^{1}$ and Christophe Boëte ${ }^{2}$ \\ ${ }^{1}$ Institut de Recherche pour le Développement (IRD), \\ Faculté de Pharmacie (UM1), Montpellier \\ ${ }^{2}$ American University of Paris, \\ Department of Computer Science, Mathematics and Science, Paris
}

France

\section{Introduction}

More than 3,400 species of mosquito have been recorded worldwide. They include 37 genera, all within a single family, the Culicidae, itself divided into 3 sub-families, Toxorhynchitinae, Anophelinae, and Culicinae. They occur in tropical and temperate zones, even above the Arctic Circle but are absent in the Antarctic. They are found as high as 6,000 $\mathrm{m}$ (above sea level) in mountainous regions and as deep as 1,250 $\mathrm{m}$ (below sea level) in caves and mines (Lane \& Crosskey, 1993).

If there is obviously an academic interest in the description and understanding of mosquito biodiversity, its study is also a major issue because of the risk associated with invasive species and the emergence and spread of vector-borne diseases. The efficiency, speed and reach of modern transport networks put indeed people at risk from the emergence of new strains of familiar diseases or completely new diseases (Guimerà et al., 2005). The global growth of economic activity, tourism, and human migration is leading to ever more cases of the movement of both diseases vectors and the pathogens they carry (Tatem et al., 2006b), increasing at the same time the biodiversity of mosquitoes around the world. In the current context of global warming, the expansion of areas suitable for the major disease vectors is becoming a threat and even a reality for some regions with several species being classified as invasive. To temperate this point, it is important to mention that among all mosquito species recorded, only $10 \%$ are regarded as efficient vectors of infectious agents having a considerable impact on human welfare and health. However, this small fraction is responsible for some of the worst scourges of humankind and the most important vectors belong essentially to three genera including Anopheles, Aedes, and Culex among which some species have been quite successful of wide-scale invasions.

An invasive species is defined as a species having a great impact on its new environment and spreading with measurable growth and distance dispersed (Daehler, 2001). Three major biological characteristics are found among the most invasive mosquito species, their close association with humans, egg resistance to desiccation (genus Aedes), and small larval habitats such as a wide variety of water holding containers among which man-made ones 
are totally suitable. Dispersal of mosquitoes can be active or passive. In the former case, mosquitoes are able to extent actively their range by flying from one habitat to another, but their flight capacity being fairly reduced (few kilometers for most of them), this natural dispersal will not allow them to quickly travel long distances. In the latter case, passive dispersal allows long-range transportation that can be either due to natural conditions (wind) or human-assisted (population movements), increasing the risk of spread of mosquitoes and vector-borne diseases. Under exceptional conditions, for instance strong winds, transport of mosquitoes is occurring on long distances into new areas. The case of the arrival of An. gambiae in Reunion Island (200 km from Mauritius) is attributed to the passage of a cyclone, and led to the first malaria epidemics in 1868 (Julvez et al., 1990). However, most of mosquito invasions are due to human-assisted transportation. For centuries, shipborne transportation allowed man to travel long distances bringing with him immature stages of mosquitoes able to cope with the transport constraints. This is especially true for Aedes aegypti and Culex quinquefasciatus that have the capacity to develop in ship water storage (Mouchet et al., 1995). Mosquito larvae that occupy small water bodies, such as natural or artificial containers, are easily transported and when the conditions are favourable, mosquitoes establish and invade new territories. Compared to other mosquito genera, Aedes eggs have the property to resist to desiccation for several months that facilitates the spread at a global scale of some species, in particular Ae. aegypti (Figs. 1A, 2) and Ae. albopictus (Figs. 1B, 3). These two Aedes species are sylvatic mosquitoes that have become closely associated with the peridomestic environment and have been transported worldwide with goods and people.

In this chapter, mosquito biodiversity is considered with a special attention to species invasions at a global or regional scale with the risk of spreading vector-borne diseases. The factors influencing mosquito invasion are examined and environmental changes are discussed. Finally, mosquito vector control strategies are exposed in relation with the question of biodiversity.

\section{The Mosquito family: The usual suspects}

\section{Mosquitoes as vectors}

Among the vector-borne diseases, malaria is probably the the most famous one, responsible for the biggest burden in terms of mortality despite the existence of methods for prevention and treatment. It is only transmitted by about 70-80 species, all of them from the genus Anopheles (Bruce-Chwatt, 1980; Manguin et al., 2008a; Mouchet et al., 2004). Less studied but still important, some of these species can also transmit other parasites such as lymphatic microfilariae (Wuchereria bancrofti, Brugia malayi, Brugia timori) (Buck, 1991; Mak, 1987; Manguin et al., 2010). It is noteworthy to mention that these microfilarial parasites are not only transmitted by Anopheles in rural areas, but also by Aedes and Culex species in urban areas. Those latter ones are also well known for their role in the transmission of various arboviruses respectively dengue, yellow fever, chikungunya for Aedes and West Nile, Japanese Encephalitis, Rift Valley for Culex species (Lane \& Crosskey, 1993).

About the complexity of classification

Numerous studies have shown that most of the vectors belong to complexes in which sibling species cannot be distinguished based on morphological characteristics alone, highlighting the importance of biodiversity in the world of mosquito vectors. Then, recent 
advances in molecular systematics have provided simple and reliable methods for unambiguous species identification and as a result increased the mosquito biodiversity with new species described based on molecular approaches (Besansky, 1999; Manguin et al., 2008b; Paskewitz et al., 1993; Smith \& Fonseca, 2004). These molecular assays are crucial to identify the correct vector species before implementing efficient control programs. Examples of misidentification due to overlapping morphological characters may have important consequences as non-vectors are targeted hampering vector control programs (Singh et al., 2010; Van Bortel et al., 2001).

Are mosquitoes just pests?

If most studies dealing with mosquitoes are related with their role in the spread of infectious diseases and the will to reduce their vectorial capacity, it appears fundamental to consider their place in the biosphere, especially as part of the food chain and the possible positive impacts they can have. Thus, some of them, Aedes communis and Aedes canadensis, are said to be involved in the pollination of orchids (Habenaria species) in North American swamps (Thien, 1969). There are however very few data on this point and this even reveals the cruel lack of ecological data on mosquitoes and especially their role in the ecosystem. This is particularly true for the ones that are not considered as public health problems. It is interesting to notice that among them, the pitcher-plant mosquito, Wyeomyia smithii has the privilege to have been the subject of investigations that have revealed that this mosquito species has evolved in response to global warming (Bradshaw \& Holzapfel, 2001). The particularity of this mosquito is that it is found only in the phytotelma of the purple pitcher plant, Sarracenia purpurea where it is the top-predator controlling the bacterial diversity in this small ecosystem (Peterson et al., 2008). Such an interest for the ecology and evolution of mosquito species is usually uncommon for species that are not considered as vector or nuisance. The development of studies in this field appears today highly needed to better understand the role of mosquitoes in community ecology, in species interactions and thus in ecosystem functioning.

\subsection{Aedes aegypti}

The yellow fever mosquito Aedes aegypti (Fig. 1A) is the principal urban vector of dengue (Fig. 2), chikungunya and yellow fever. It is an African species closely associated with humans: it feeds on human blood (anthropophilic), although not exclusively, and breeds in the peridomestic environment in artificial containers. Maritime dispersal in the Mediterranean region - in ships carrying infested water storage vessels - may have begun as early as 1000 B.C. From the $16^{\text {th }}$ century onwards the species invaded the Americas, carried from Africa in slave ships (Tabachnick \& Walter, 1991). The transatlantic passage generally took six to eight weeks, during which water storage containers must have been a prolific breeding site and the slaves and crew a ready source of blood. In consequence, it was not unusual for ships to arrive with an active yellow fever epidemic onboard (Rodhain, 1996), hence the yellow flag that still signifies a ship in quarantine.

The species was quick to colonise the New World, and this was accompanied by repeated and devastating yellow fever epidemics in seaports as far north as Boston (MA) and in inland cities such as Memphis (TN) and St Louis (MO). Aedes aegypti is now widespread in tropical Americas and has been recorded in 21 states of the United States (Gubler \& Clark, 1995; Reiter, 2010b). From the mid-19th century onwards, it became widespread and common in much of India and Southeast Asia, probably accelerated by an increase in 
seaborne trade. Curiously, yellow fever has never been documented in the region, but dengue and chikungunya quickly became endemic and are now a major health problem. In the Polynesian islands, dispersal of Ae. aegypti between 1924 and 1986 has been attributed in large part to the construction of new airports (Mouchet et al., 1995; Séchan et al., 1993). Although well-established, often common in sub-tropical and many temperate regions, it disappeared from the entire Mediterranean region after World War II, perhaps because of widespread use of DDT for malaria eradication. In the past two decades it has become scarce in many regions of the United States; this has been attributed to the spread of a second introduced species, the Asian Tiger mosquito Ae. albopictus (Hobbs et al., 1991; Lounibos et al., 2010; O'Meara et al., 1995; Reiter, 2010b).
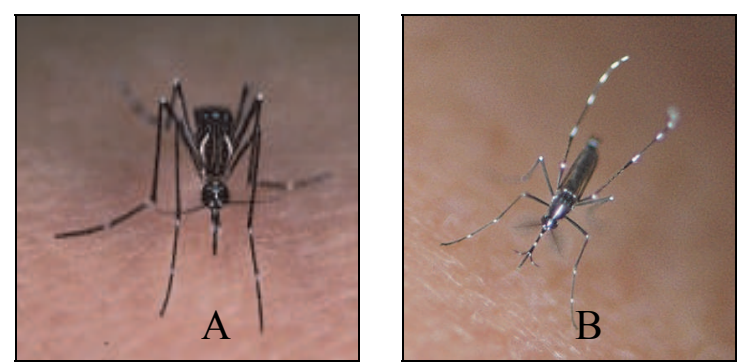

Fig. 1. A, Adult female Aedes (Stegomyia) aegypti (Photo @ IRD/Jean-Pierre Hervy) and B, Adult male Aedes (S.) albopictus (Photo (C IRD/Michel Dukhan). These species are the principal urban vectors of dengue and chikungunya throughout the world

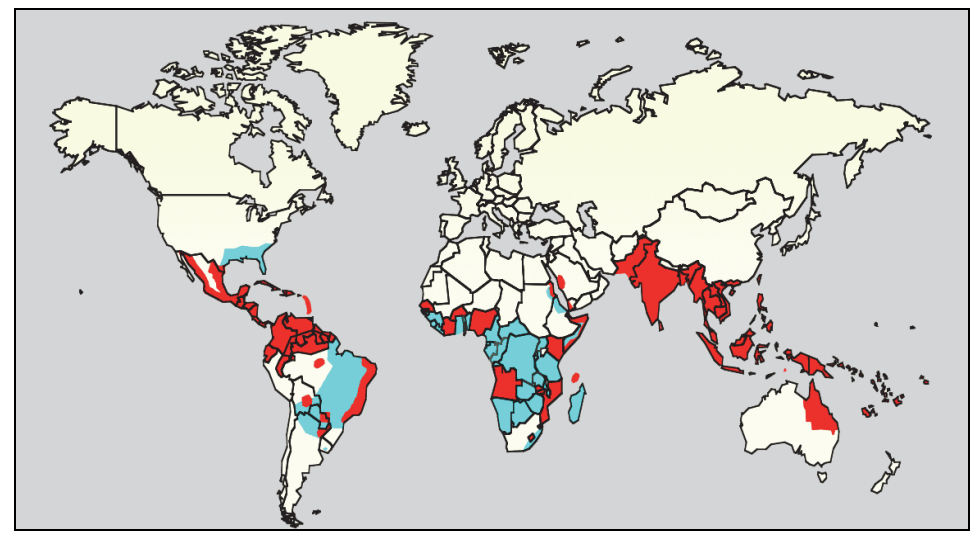

Fig. 2. Worldwide distribution of Aedes aegypti and Dengue fever in 2006; in blue, areas infested with Ae. aegypti; in red, areas with Ae. aegypti and recent epidemic dengue fever (Map by G.G. Clark, Public Domain)

\subsection{Aedes albopictus}

Although Aedes albopictus, the Asian Tiger mosquito (Fig. 1B), is widespread in urban areas, it is not restricted to the peri-domestic environment and feeds readily on many species of vertebrates. Until the mid-20th century, the only established populations outside Asia were 
in the Hawaiian Islands, Madagascar, several small islands in the south-western Indian Ocean and various islands in Polynesia and other regions of the Pacific, but in the 1970s a new infestation appeared in Albania and the species quickly became widespread and abundant. In 1983, the appearance of a single specimen in Memphis (TN, United States) was attributed to container transportation (Reiter \& Darsie, 1983) and this was confirmed in 1985 when widespread infestations throughout the southern United States were traced to a global trade in used tires, with millions of tires exported from various countries in Asia, particularly Japan (Hawley et al., 1987; Reiter \& Sprenger, 1987). Laboratory studies revealed that strains from northern Asia are cold-hardy and exhibit a winter diapause that is progressively absent at lower latitudes (Hawley et al., 1987); these mechanisms presumably limit potential range in newly infested countries. In the United States, the species is now established as far north as Nebraska and Illinois where temperatures below $-20^{\circ} \mathrm{C}$ are not uncommon. In 1988, Ae. albopictus reached Mexico (probably exported from the United States) and spread into all countries of Central America. The species was already present in Brazil (1985) and is now occurring throughout South America, except Chile (Forattini, 1986; Reiter, 2010b). It has spread rapidly in Africa, with infestations identified in southeast Nigeria (1991), Cameroon (2000), Equatorial Guinea (2003), Gabon (2007), Central African Republic (2010), Algeria (2010) (Diallo et al., 2010; Fontenille \& Toto, 2001; Gubler, 2003; Izri et al., 2010; Pages et al., 2009; Toto et al., 2003) and is also reported from Lebanon, Syria and Israel (Reiter, 2010a). Likewise in Europe: it is now present and well established in at least 14 countries, including Italy (1991), France (1999),

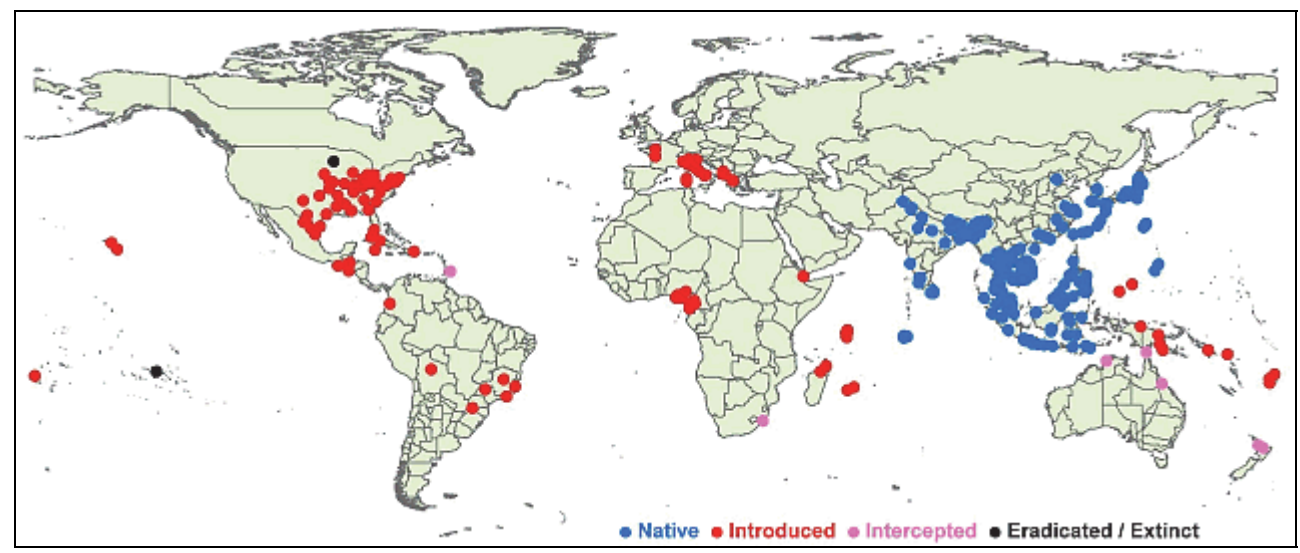

Fig. 3. Worldwide distribution of Aedes albopictus in 2004; in blue: native distribution; in red: invaded areas; in pink: intercepted specimens; in black: species eradicated or extinct (Map courtesy of Landcare Research New Zealand Limited 2005, available on www.landcareresearch.co.nz). More countries have now been infested (see text above)

Spain (2006), as well as Switzerland, several countries in the Balkans and Malta (Aranda et al., 2006; Dalla Pozza \& Majori, 1992; Reiter, 2010b; Schaffner \& Karch, 2000; Scholte \& Schaffner, 2007). Compared to Ae. aegypti, its vectorial capacity is generally held to be low because it is not host specific (Gratz, 2004; Gubler, 2003) and virus dissemination from midgut into salivary glands occurs at lower rates (Lambrechts et al., 2010). However, recent outbreaks of dengue (Hawaii, 2001-02) and chikungunya (Reunion Island, 2005-06; Italy 
2007; Gabon 2007) confirm that Ae. albopictus can function as an epidemic vector, at least under certain conditions (Effler et al., 2005; Pages et al., 2009; Renault et al., 2007). The accelerating expansion of global air travel for business and tourism, and the rapid rise in the prevalence and incidence of urban transmission in the tropics guarantee that such outbreaks are likely to become increasingly common. This growing risk shows the need for implementation of regular monitoring of populations as the vectorial status is a dynamic process that may evolve towards greater efficiency (Lambrechts et al., 2010). The potential role of Ae. albopictus acting as bridge vector of more arboviruses, such as yellow fever (Reiter, 2010a), to be brought into peridomestic environments, increasing the risk of human infection, is feared and calls for a close surveillance.

\subsection{Other Aedes or Ochlerotatus species}

Other species of Aedes or Ochlerotatus, two genera of the Aedini tribe (Reinert et al., 2004), have invaded new territories, including Ochlerotatus (Ae.) japonicus in North America and Hawaiian Islands (Fonseca et al., 2010; Hughes et al., 2008; Larish \& Savage, 2005) and Central and Western Europe (Schaffner et al., 2004; 2009), Ae. bahamensis in south Florida (O'Meara et al., 1989), Oc. (Ae.) atropalpus in Italy (Romi et al., 1997) and in the Netherlands (Scholte et al., 2009), and Ae. togoi in the Pacific Northwest (Belton \& Belton, 1990) and Malaysia (Ramalingam, 1969).

\subsection{Culex pipiens complex}

Mosquitoes in the Culex pipiens complex are ubiquitous in tropical, subtropical and temperate regions in urban, suburban and rural habitats worldwide (Smith \& Fonseca, 2004). They are important as vectors of a number of arboviruses in temperate and tropical regions (e.g. West Nile Virus, Rift Valley, St. Louis encephalitis, Japanese encephalitis) and parasites including Bancroftian filariasis and a large number of avian protozoans.

In the tropics and sub-tropics Culex pipiens quinquefasciatus (Figs. 4, 5) is the classic species in water highly contaminated with organic material, even in latrines and septic tanks, but it also breeds in cleaner water in artificial containers, often sympatric with Ae. aegypti. The pathways of global expansion of this species appear to have followed those of Ae. aegypti. There is evidence that it invaded Australia between the end of the $18^{\text {th }}$ century and early $19^{\text {th }}$ century (Marks, 1972) and New Zealand at some time prior to 1848 (Weinstein et al., 1997). Its appearance on Maui, in the Hawaii Islands (the first mosquito to do so) is attributed to the arrival of ships from Mexico around 1826 (Dine, 1904), but this was undoubtedly followed by multiple additional introductions (Fonseca et al., 2000). The presence of the species, in conjunction with the arrival the European House Sparrow (Passer domesticus) infected with the avian malaria parasite Plasmodium relictum had a catastrophic impact on the unique local avifauna; many species became extinct and others only survive at altitudes too high for mosquito-borne transmission (Fonseca et al., 2000; Van Riper et al., 1986). Colonisation of the Pacific islands appears to have been linked to military movements during World War II as well as marine trade with Australia (Belkin, 1962). Introduction of Cx. p. quinquefasciatus in the New World also appears to have been recent but the pathway is unclear. On the African and Asian continents, populations present a high allelic richness that suggests multiple introductions from different sources (Fonseca et al., 2006). The common House Mosquito, Culex p. pipiens, is probably of European origin. Winter diapause in the adult stage, and the ability to survive in sub-zero temperatures have enabled it to 
colonise temperate regions of north and south America (Lane \& Crosskey, 1993; Vinagradova, 2000).

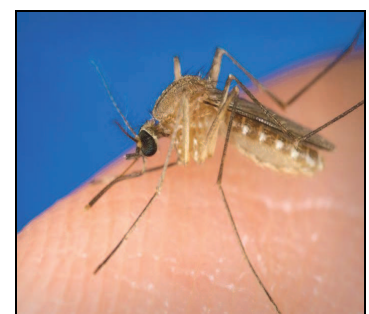

Fig. 4. Adult of Culex quinquefasciatus (Photo courtesy CDC/James Gathany)

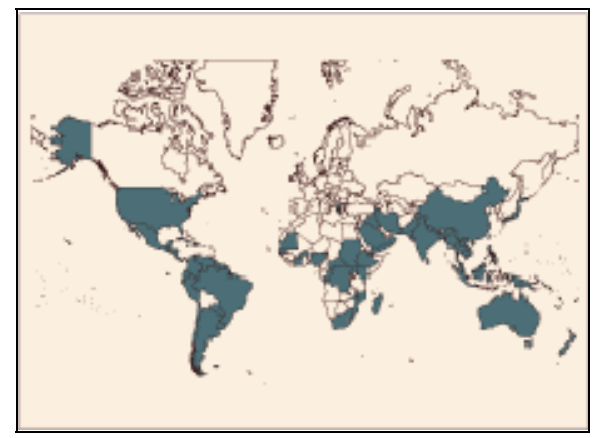

Fig. 5. Worldwide distribution map of Culex quinquefasciatus in 2010 (Map courtesy of WRBU, USA, www.wrbu.org)

\subsection{Anopheles species}

The reduction of travel time with faster ships or aircrafts allowed the transportation of more mosquitoes, as well as other genera that require specific environment for reproduction such as Anopheles. This major change in travel velocity has provoked cases of invasion of Anopheles vectors. In 1864, the opening of the Tamatave-Port-Louis steam boat line was immediately followed by the invasion of An. gambiae s.l. (Fig. 6), major vector of Plasmodium falciparum malaria in Africa (Fig. 7), from Madagascar to Mauritius, a malaria-free island prior to this introduction. One year later, the first malaria epidemics burst in the harbour of Mauritius and propagate all over the island (Mouchet et al., 1995).

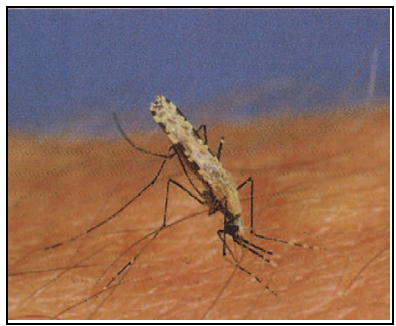

Fig. 6. Anopheles gambiae (Photo @ IRD /Jean-Pierre Hervy) 


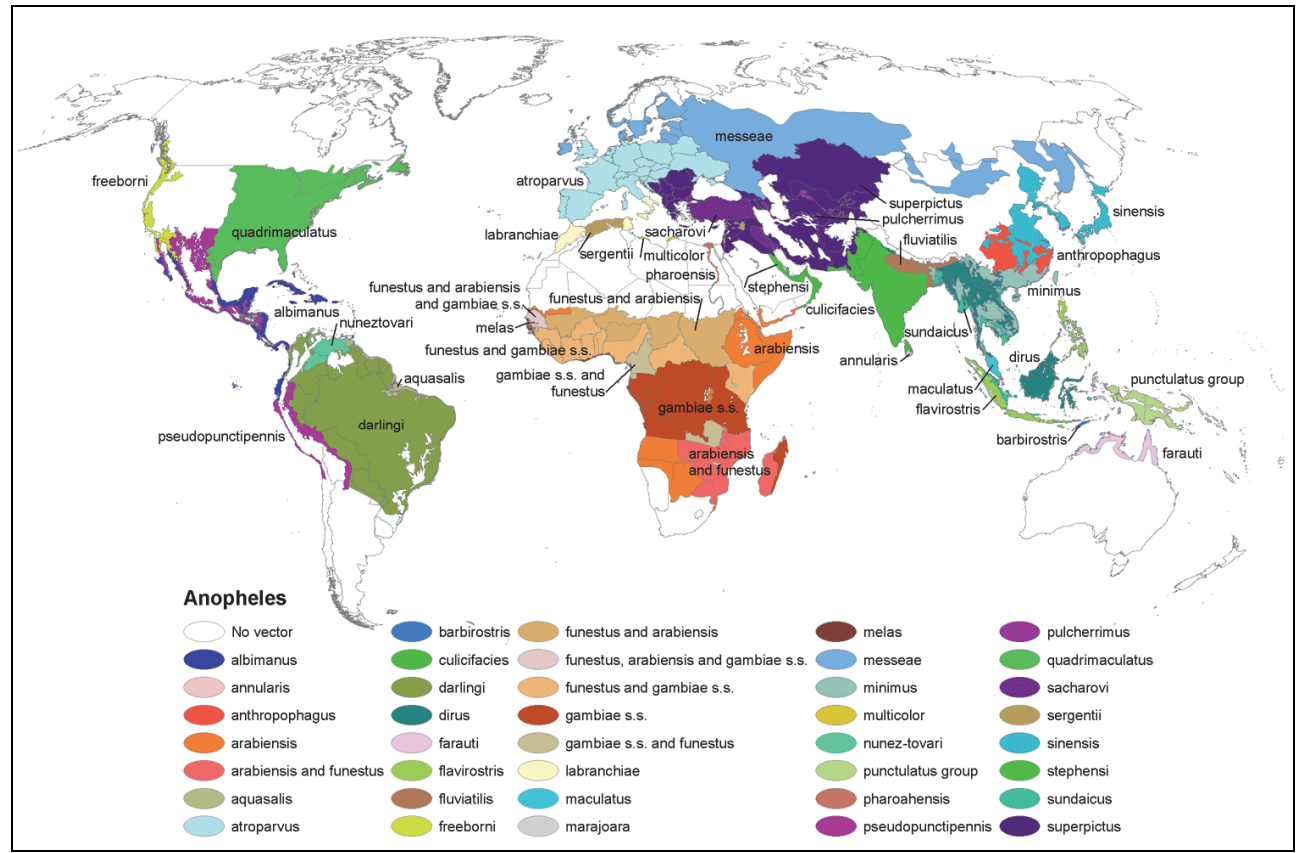

Fig. 7. Anopheles mosquito range map (U.S. CDC, Public Domain)

However, the most famous Anopheles vector invasion concerns the devastating introduction of An. gambiae s.l., specifically An. arabiensis (Parmakelis et al., 2008) which is one species of the Gambiae Complex, from Africa to north-eastern Brazil in 1930 (Soper \& Wilson, 1943). Anopheles females were most likely transported from Dakar (Senegal) to Natal (Brazil) in a fast ship (sloop) which was regularly crossing the Atlantic Ocean (Rodhain, 1996). The environmental conditions found in Natal were close to the ones of the native area; therefore the species gradually invaded the north-eastern part of the country to cover $54,000 \mathrm{~km}^{2}$ after 10 years, spreading malaria and killing 16,000 persons (Killeen et al., 2002). Malaria was already endemic in Brazil but the local vectors were not as efficient as the African vector, An. arabiensis, in disseminating falciparum malaria. One might also wonder about the role played by the interaction between African Anopheles and South American malaria parasites. Although costly, the military organisation of the vector control program, based on the systematic suppression of larval habitats and the use of Paris Green in larval sites that could not be eliminated, was successful as the species was eradicated by 1940 from Brazil (Soper \& Wilson, 1943).

In 1942, another invasion by An. gambiae s.1., presumably An. arabiensis again, was reported in Upper Egypt, spreading $850 \mathrm{~km}$ along the Nile River. The vector was most likely imported by boats from Sudan as transportation was greatly increased during this period of war. This invasion was followed by a major malaria epidemic responsible for an estimated 12,000 deaths (Shousha, 1948). Based on the same energetic vector control methods than in Brazil (Paris Green against larvae and insecticide spraying against adults), An. gambiae s.l. was eradicated by 1945 (Shousha, 1948). 
With the era of aircraft transportation, the travel time has been reduced so much that in less than two days an insect could reach almost any point of the world, as well as an infected person. The phenomenon called "airport malaria" is due to the introduction of Anopheles vectors from an endemic area to a non-endemic one where people, living near international airports but who never travelled to a malaria-risk area, can be infected. The highest risk comes from western and central Africa as most of the air traffic includes stopover in west European airports. Among the numerous Anopheles mosquitoes found in these international airports, An. gambiae s.l. (An. gambiae or An. arabiensis), the most efficient malaria vector in the world, is frequent during the hot summer period (July-August) as climatic conditions coincide with the region of origin (Mouchet, 2000). However, in the case of airport malaria, the infected tropical Anopheles mosquito has very poor chance of development as temperate climate is unfavourable to its establishment. Even the growth of travel back and forth to endemic areas presents a negligible risk of invasion of Anopheles vectors in temperate regions but this risk increases in tropical and subtropical areas where the climate barrier is absent.

The constant increase in sea and air traffic raises the risk of introducing new vectors, especially through shipment of goods and small aircrafts that introduced numerous mosquito species worldwide contributing locally to an increase of the biodiversity. Reports show for instance that all five mosquito species found in Hawaii are non-indigenous, as well as 17 of Guam's 24 species (only 7 are endemic) (Lounibos, 2002). However, most vector invasions, especially in regions where resources for correct entomological surveys are lacking, go unnoticed because of a lack of surveillance. Only few regions in the world are controlling invasive mosquitoes and a future universal reporting system as well as qualified personal need to be implemented. Multiple introductions of the same invasive species seem to be a fundamental evolutionary factor that may also play a role on changes in pathogen virulence which impacts important epidemiological parameters as shown in Hawaii with the increase in the altitudinal range of $C x$. quinquefasciatus and the differences in vector competence to avian malaria after the second introduction of the vector (Fonseca et al., 2006).

\section{Factors influencing mosquito invasion}

Most successful mosquito invaders have arrived by ships (Fig. 8) (Calder \& Laird, 1994). However, this mode of transportation implies that the imported mosquitoes are able to cope with travel conditions and the length of journey that can last months for sailing vessels. Desiccation-resistant eggs are strongly associated with becoming an introduced species (Juliano \& Lounibos, 2005). Thus Aedes species can travel in large numbers at the egg or immature stages which enhance survival in non-native environments and greatly increase their probability of population establishment (Grevstad, 1999). For aircraft transportation, mosquitoes mainly travel at the adult stage and typically in low numbers. Although, this type of transportation is quick allowing any mosquito to reach its destination in several hours, the success of invasion is poor because the probability of population establishment decreases as lower number of specimens is released. However, some successful invasions after aircraft transportation have been reported, such as $A e$. albopictus in Hawaii (Kilpatrick et al., 2004) and Ae. aegypti in Polynesian islands (Mouchet et al., 1995; Séchan et al., 1993). 


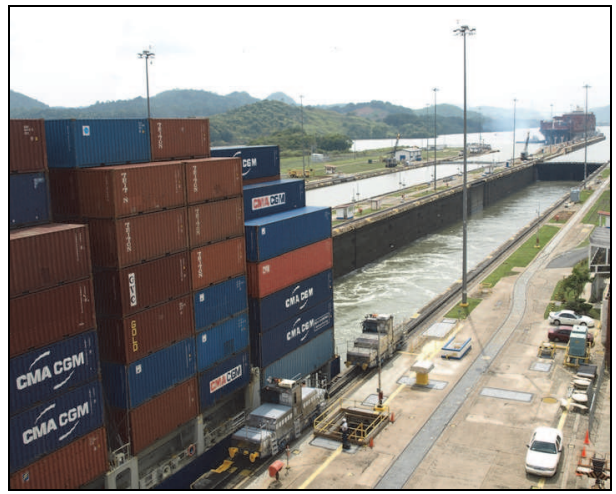

Fig. 8. Cargo loaded with containers passing the Panama Canal in 2010 (Photo S. Manguin)

Global village ... also for mosquitoes

The risk of vector invasion is now constantly present and even increasing as transport networks continue to expand in reach, speed of travel, number of travellers and goods carried. This expansion of the global traffic is associated with an increase of biological invasions which may cause nuisance and threats to human health (Tatem et al., 2006a). The vectors and the pathogens they carry can now move further, faster and in greater numbers than ever before. The current main road of mosquito invaders goes from Asia to Americas which corresponds to the predominant direction of tire shipments (Reiter, 1998). The combination of traffic volumes and climatic appropriateness can explain a great deal of invasion pathways of most cosmopolitan vectors, as shown for Ae. albopictus (Tatem et al., 2006a). The establishment of a vector in a new area requires several conditions, which vary from a species to another. The environment and the type of larval habitats are major components that will allow either the global invasion of new vector species (e.g. Ae. albopictus), or its establishment in a new area due to environmental changes (e.g. global warming), or will restrict it to specific areas. The immature stages of Anopheles species tend to develop in more natural larval habitats, although anthropogenic sites have been reported such as wells, domestic tanks, etc. For Aedes and Culex, their habitats are highly anthropogenic, and thus suitable for invasion and extension of their geographic distribution. Although most recorded invasions concern Aedes species and to a lesser extent Culex species, the establishment and spread of Anopheles species, in particular An. gambiae or its sister species An. arabiensis, could be devastating as proved by the few examples related above. The former species occurs in hotter and wetter climates of sub-Saharan Africa compared to the latter one that prefers drier environments as found during the invasions of Northeastern Brazil or Upper Egypt. This specificity linked to each species led Tatem et al. (2006a) to speculate on the most favourable regions that could be invaded outside Africa, such as Southeast Asia and Central/South America for An. gambiae and Middle East and Canary Islands for An. arabiensis, although it was this latter species that invaded the north-eastern part of Brazil in 1930 (Parmakelis et al., 2008). These high-risk regions of invasion by the most efficient malaria vectors in the world have been defined based on the combination of local climate and volume of sea traffic. However, this risk is relatively small as the sea traffic volumes from sub-Saharan Africa are still quite low compared to the Asian traffic. To the level of traffic volume and the appropriate environment, it is important to add biological 
traits that favour mosquito transportation. Anopheles mosquitoes are a lot less adapted to man-made larval habitats and to urban areas than Aedes or Culex species. Therefore, their transportation is mainly occurring at the adult stage and in low numbers and this greatly reduces the success of invasion. As a consequence, the distribution of the Anopheles species is either regional or local (Fig. 7), but no species has a cosmopolitan distribution such as Aedes (Figs. 2, 3) or Culex (Fig. 5) species (Hay et al., 2010; Lounibos, 2002; Mouchet, 1999).

\begin{tabular}{|c|c|c|c|}
\hline Mosquito genus & Anopheles & Aedes & Culex \\
\hline $\begin{array}{l}\text { Main invasive } \\
\text { phase }\end{array}$ & $\begin{array}{l}\text { Terrestrial phase } \\
\text { (adults) }\end{array}$ & $\begin{array}{c}\text { Aquatic phase (eggs, } \\
\text { larvae) }\end{array}$ & $\begin{array}{c}\text { Aquatic phase (eggs, } \\
\text { larvae) }\end{array}$ \\
\hline $\begin{array}{l}\text { Main human- } \\
\text { assisted } \\
\text { introduction mode }\end{array}$ & $\begin{array}{l}\text { Airplanes, speed } \\
\text { boats, cars (few } \\
\text { hours to days) }\end{array}$ & $\begin{array}{l}\text { Small containers } \\
\text { (domestic water jars, } \\
\text { tires) in ships (few } \\
\text { days to several } \\
\text { months) }\end{array}$ & $\begin{array}{c}\text { Small containers } \\
\text { transported by ships } \\
\text { (few days to several } \\
\text { months) }\end{array}$ \\
\hline $\begin{array}{c}\text { Biological } \\
\text { characteristics }\end{array}$ & & $\begin{array}{l}\text { Eggs resistant to } \\
\text { desiccation }\end{array}$ & \\
\hline $\begin{array}{l}\text { Major invasive } \\
\text { vectors } \\
\text { (origin to invaded } \\
\text { regions) }\end{array}$ & $\begin{array}{c}\text { An. arabiensis } \\
\text { (Africa to } \\
\text { Mauritius, Brazil, } \\
\text { Upper Egypt) }\end{array}$ & $\begin{array}{c}\text { Ae. aegypti (Africa to } \\
\text { cosmopolitan), Ae. } \\
\text { albopictus (Asia to } \\
\text { Americas, Europe, } \\
\text { Africa) }\end{array}$ & $\begin{array}{l}\text { C. pipiens (Old World } \\
\text { to North America), C. } \\
\text { quinquefasciatus (Africa } \\
\text { to Americas, Asia, } \\
\text { New Zealand, } \\
\text { southern Europe) }\end{array}$ \\
\hline $\begin{array}{l}\text { Major associated } \\
\text { vector-borne } \\
\text { diseases }\end{array}$ & Malaria & $\begin{array}{l}\text { Dengue, yellow fever, } \\
\text { chikungunya }\end{array}$ & $\begin{array}{c}\text { West Nile, Japanese } \\
\text { Encephalitis, Rift } \\
\text { Valley }\end{array}$ \\
\hline
\end{tabular}

Table 1. Characteristics of invasion by the main mosquito genera

Other barriers exist such as competition from local mosquitoes that represents an obstacle for the development of the alien species (Hay et al., 2005). In addition, equilibrium with competitors, predators and local pathogenic agents must be reached in order to have a productive larval development in new ecosystems. In Mauritius, as both An. arabiensis and An. funestus were imported, the latter species was eradicated after insecticide vector control while the other one persisted (Mouchet et al., 1995). The invasion of An. arabiensis in Brazil was stopped and the species eradicated by larvicide use (Soper \& Wilson, 1943), whether this vector control is not efficient in Africa. This is most likely due to the precarious adaptation of this imported species into a new environment (Mouchet et al., 1995). More cases of imported Anopheles species eradication or spontaneous disappearance have been reported. The same occurred for some cases of imported Aedes vectors, for instance with the elimination of Ae. aegypti from the Mediterranean Basin and Ae. albopictus from a Polynesian atoll (Taiaro Island, Tuamotu Archipelago) where it was intentionally introduced to take over from Ae. polynesiensis which is the local vector of lymphatic filariasis. The nonindigenous species failed to displace the native vector and within 1-4 years disappeared from the island (Rosen et al., 1976). 


\section{How is the mosquito biodiversity distributed around the world?}

As stated in the introduction, mosquitoes are occurring worldwide, except in the Antarctic. They occur heterogeneously around the world. Anopheles mosquitoes for instance are absent from islands such as Greenland, Iceland, the Seychelles, New Caledonia and islands of central and eastern Polynesia (Fig. 7) (Mouchet et al., 2004; Robert et al., 2011). Several studies on mosquito biogeography have shown that the highest biodiversity of mosquitoes occurs in Southeast Asia and the Neotropics (Gaston \& Hudson, 1994). There is a latitudinal biodiversity gradient with species richness increasing toward the equator (Foley et al., 2007) and several Asian countries, including Indonesia, Malaysia, and Thailand, along with Brazil have the highest numbers of mosquito species. Based on the 24 Anopheles species complexes currently recognized (Carvalho-Pinto \& Lourenço-de-Oliveira, 2004; Coetzee et al., 1999; Harbach, 2004; Krzywinski et al., 2011; Manguin et al., 2008b; Narang et al., 1993), 12 occur in Asia (50\%) while 5, 3, 3, and 1 are respectively distributed in Americas (21\%), Africa (13\%), Australia-Pacific (13\%) and Europe (4\%) (Table 2). In addition, Anopheles species

\begin{tabular}{|l|l|}
\hline Anopheles species Complex (Subgenus) & Distribution \\
\hline Albitarsis (Nyssorhynchus) & Americas \\
Annularis (Cellia) & Asia \\
Annulipes (Cellia) & Australia-Pacific \\
Barbirostris (Anopheles) & Asia \\
Benarocchi (Nyssorhynchus) & Americas \\
Claviger (Anopheles) & Europe \\
Crucians (Anopheles) & Americas \\
Cruzii (Kerteszia) & Americas \\
Culicifacies (Cellia) & Asia \\
Dirus (Cellia) & Asia \\
Farauti (Cellia) & Australia-Pacific \\
Fluviatilis (Cellia) & Asia \\
Gambiae (Cellia) & Africa \\
Gigas (Anopheles) & Asia \\
Leucosphyrus (Cellia) & Asia \\
Lindesayi (Anopheles) & Asia \\
Lungae (Cellia) & Australia-Pacific \\
Marshallii (Cellia) & Africa \\
Minimus (Cellia) & Asia \\
Nili (Cellia) & Africa \\
Nivipes (Cellia) & Asia \\
Nuneztovari (Nyssorhynchus) & Americas \\
Subpictus (Cellia) & Asia \\
Sundaicus (Cellia) & Asia \\
\hline Total: 24 & Asia (12), Americas (5), Africa (3), \\
\hline
\end{tabular}

Table 2. Anopheles species complexes in relation to their geographic distribution 
richness in collecting sites is higher in Asia, with more than 10 species per site, often reaching 12 to 15 species and up to 20 species in some localities (Coosemans et al., 2006; Garros et al., 2008), compared to generally less than 10 species per site, even less than 5 species, on the American and African continents (based on the combination of different collecting methods) (S. Manguin, unpublished data).

\section{Mosquito biodiversity, human health and environmental change}

Introduced vectors may have a serious impact on human health either by simultaneously introducing a novel pathogen (e.g. Ae. aegypti and yellow fever/dengue in Americas, airport malaria cases), by spreading a native pathogen (e.g. An. arabiensis and P. falciparum malaria in Brazil, Ae. aegypti and dengue in Asia), or by the independent introductions of a nonnative vector and novel pathogen (e.g. C. pipiens and West Nile virus in America, Ae. albopictus and chikungunya epidemics in Indian Ocean islands and outbreaks in Europe) (Juliano \& Lounibos, 2005). Climate is obviously an important factor for the spread of most invasive mosquitoes. In addition to transportation, global climate changes could indeed increase the risk of vector invasion and the spread of vector-borne diseases even under temperate climate (Rogers et al., 2001). This adds to the constant increase in international transportation that is a major issue in the dispersion of vectors and pathogens. This needs to be monitored on a regular basis and at a global scale in order to prevent from emerging disease epidemics. In a more general way, travel is a potent force in vector invasion along with disease emergence and spread, and the continued growth in global air travel and shipborne trade is increasing the risk of disease vector invasions (Tatem et al., 2006b). As transport links are becoming busier and further between spatially distant, but climatically similar regions of the world, global transportation by seaborne or through the worldwide airline network increases the risks of deliberate or accidental movements and establishment of climatically sensitive exotic organisms in new areas (Tatem, 2009). With traffic levels continuing to rise and climates changing regionally, these risks will vary, both seasonally and year-by-year.

Beside invasion of some mosquito species, there is a confirmed loss of biodiversity from anthropogenic origins and this may greatly affect human health. Variation in the diversity of vertebrate hosts may indeed have an influence on the risk of human exposure to vectorborne diseases. High biodiversity can protect human health by reducing the risk of disease transmission due to the diversity of hosts, also called the "dilution effect" (Ostfeld \& Keesing, 2000). On the contrary, reduced biodiversity can increase the risk of disease transmission by concentrating the source pool on few available and competent hosts, unless the biodiversity loss causes the reduction in competent and amplifying hosts (Keesing et al., 2010). This is valid under four conditions: (1) the vector is generalist, able to blood feed on several hosts, such as Ae. albopictus. However, this condition is not verified for the main mosquito vectors of human diseases as they generally present an anthropophilic behaviour, such as An. gambiae or Ae. aegypti. In this case, the dilution effect is not reducing disease transmission as the vectors feed almost exclusively on humans. (2) The vector acquires pathogens from its hosts through its biting behaviour. Although some Aedes and Culex species may get infected by a transovarial transmission, the large majority of mosquito vectors contract pathogens after an infected bite. (3) The reservoir host is competent for transmitting pathogens. (4) Most competent reservoir host tends to be a community dominant. When all four conditions are met, high diversity in the community of hosts 
strongly reduces the transmission of vector-borne diseases. Ostfeld (2009) has well documented the effect of biodiversity loss on the increase of vector-borne zoonotic disease transmission; on the contrary, the preservation of intact ecosystems and their endemic biodiversity should reduce the prevalence of some infectious diseases, in particular transmission of zoonotic pathogens such as West Nile Virus and Culex vectors (Keesing et al., 2010). Therefore, in certain cases, biodiversity may play a dual role in the emergence and transmission of vector-borne diseases with high diversity providing a larger potential source of novel pathogens and vectors, and in the meantime biodiversity can reduce pathogen transmission.

Other studies showed that, in the case of malaria vectors, changes in aquatic predator diversity can have a major impact on larval population and therefore on infectious disease risk. Larval habitat disturbance markedly reduced the predator diversity which had for consequence to increase the density of An. gambiae (Carlson et al., 2009). As human population increases, urbanization and environmental changes due to an expansion of land cultivation is occurring at a faster pace. Ecological disturbance and development of irrigation is participating in the increase of malaria, as demonstrated in Africa (Minakawa et al., 2006; Mouchet et al., 1998). Deforestation is obviously one of these types of disturbance. A forest is a closed environment that favours main vectors such as An. dirus in Asia, but forest clearing for cultivation has resulted in the development of more heliophilic vectors, such as An. harrisoni in Southeast Asia (Manguin et al., 2008b). A similar situation also occurred in Africa with An. gambiae (Livadas et al., 1958). Dam, irrigation ditches, rice fields, and borrow pits made for bricks used in the construction of houses, constitute favourable larval habitats for An. gambiae and An. arabiensis and in the latter case the mosquito find next to each other suitable larval habitats and human blood source (Mouchet \& Brengues, 1990). In central African highlands, the natural marshes of papyrus, that produces a layer of oil at the water surface inhibiting the anopheline larval development, has been widely replaced by cultivation of valley bottom for food crops and fish ponds offering suitable mosquito habitats. This land use change led to the rapid development of An. gambiae and, in 1994, a deadly malaria epidemic burst in a region of Uganda located above 1,500 meters of altitude and previously considered nearly malaria-free (Mouchet et al., 1998). In association to the environmental change due to the demographic pressure, the climate with abnormal rainfall, more than 2-fold a normal year, was also a determinant factor that induced this epidemic. Finally, it is noteworthy that zones of unstable malaria are more sensitive to environmental changes and climatic variations than stable malaria regions (Mouchet et al., 1998).

\section{Vector control strategies}

While Anopheles species are distributed into distinct biogeographical zones, the main Aedes and Culex vector species have a worldwide distribution with some invasive species, such as Aedes albopictus being the current example of a rapid and efficient global spread responsible for epidemics of dengue and chikungunya. Each continent has its main malaria vectors (Hay et al., 2010; Mouchet et al., 2004), among them Anopheles gambiae, An. arabiensis and An. funestus being the most efficient ones in sub-Saharan Africa (Sinka et al., 2010a); An. darlingi, the main vector in Latin America (Sinka et al., 2010b); An. culicifacies s.l., An. dirus s.l., An. fluviatilis s.l., An. maculatus, An. minimus s.l., and An. stephensi in Asia; and An. farauti s.l., An. koliensis and An punctulatus in the Australian-Pacific region (Sinka et al., 2011). In comparison, the distribution of species such as Aedes aegypti covers the tropical belt across 
all continents (Fig. 2) or is cosmopolitan as for Culex quinquefasciatus (Fig. 5) (WHO, 1989). This fundamental difference has important consequences on vector control strategies with global control programs that may be applied at a continental scale in the latter case, when regional strategies need to be developed in the case of Anopheles mosquitoes.

Vector control strategies are mainly based on three fundamental methods: (1) physical control such as the destruction of larval habitats by environmental modifications, (2) chemical control based on insecticide use, (3) biological control by use of biolarvicides (Rozendaal, 1997).

\subsection{Physical control}

Physical control is possible by removing larval sites (containers, water deposits), especially efficient against Aedes or Culex species. Larval habitats can also be altered such as drainage operations, intermittent irrigation, change in river discharge or configuration, removal water plants or algae, making habitats unsuitable. Few interesting results against Anopheles mosquitoes have been reported but they require massive engineering efforts (Mouchet et al., 2004).

\subsection{Chemical control}

The chemical control is based on insecticide impregnation of material, as well as regular spray of insecticides/larvicides by terrestrial or airways according to the nature of the habitats and their size. Vector control programs against Anopheles mosquitoes are mainly based on the use of insecticide-treated nets (ITN), long-lasting insecticidal nets (LLINs), or indoor residual spraying (IRS) which remain effective methods of control when used properly. Larviciding can also be implemented in special situations (well known breeding sites mainly man-made). The use of different insecticides in rotation or mosaic can also be recommended in order to avoid (or at least delay) the problems of resistance (Hemingway et al., 1997; Lenormand \& Raymond, 1998). In association to larval habitat removal, vector control program against Aedes mosquitoes based on insecticidal spraying (organophosphates, pyrethroids) using hand-held apparatus, road vehicle or aircraft presents some efficacy. However, for Ae. aegypti which tends to rest inside houses, indoor spraying is more appropriate. For Ae. albopictus, vector control appears to be more difficult due to its ability to breed away from humans, but its outdoor resting behaviour makes outdoor spraying an effective strategy of control. Two pyrethroid insecticides, alphacypermethrin and lambda-cyhalothrin, applied uniformly to the inside surfaces of either dry tires that were partially filled with water $24 \mathrm{~h}$ after spraying, or wet tires partially filled with water prior to spraying showed their efficacy to prevent mosquito larval colonization in disused car tires. Both insecticides using either application method show great potential for the prevention of invasion against Ae. aegypti and Ae. albopictus (Pettit et al., 2010).

\subsection{Biological control}

Some organisms have proved to be effective against mosquito larvae such as larvivorous fish (Gambusia, Poecilia), predatory insect larvae (dragonfly, Toxorhynchites mosquitoes), copepods, nematode worms, fungi, and bacterial larvicides. The latter ones have concentrated much attention. Thus, Bacillus sphaericus is widely used against Culex species (Skovmand et al., 2009), while megadoses of dry formulations of Bacillus thuringiensis subspecies israelensis (Bti) proved to be efficient for residual control of Ae. aegypti in small 
containers (Ritchie et al., 2010). Recent studies have also shown that the use of entomopathogenic fungi could provide an interesting tool having the advantage to be evolution-proof (Blanford et al., 2005; Read et al., 2009; Scholte et al., 2005).

\subsection{What about keeping mosquitoes and replacing the vectors}

It is interesting here to mention that the current methods are aiming at reducing (or eliminating) mosquito populations and vector species. A recent debate has taken place on the question "What would happen if there were no more mosquitoes?" Despite the collateral damage of eradicating mosquitoes that would result in the loss of a group of pollinators and a primary food source for many species, a world without mosquitoes could be seen as more secure to us, in particular the elimination of Anopheles would be quite beneficial for mankind (Fang, 2010; Wickson, 2010). However, the limitations in mosquito control strategies make a world without mosquitoes unlikely (Fang, 2010). In addition, the real impact on ecosystems worldwide is difficult to apprehend, especially as discussions undergone illustrate the nadir in which mosquito ecology lies. In relation with the role of mosquitoes in the ecosystem, it is interesting to notice that among the current effort in developing a transgenic approach against vector-borne disease, one envisaged method is to replace populations of vectors by non-vectors. Even if the relevance of this is highly debated (Boëte, 2006), one might consider that it would have the advantage to leave mosquitoes in the food chain but the balance between this advantage and the potential adverse effects needs to be properly evaluated.

Nowadays and in the current efforts to reduce the burden of vector-borne diseases, the implementation of integrated vector management (IVM) activities that combine the use of different control strategies in relation to local vector bionomics appear the best strategy to move forward (Chanda et al., 2008).

\section{Conclusions}

Aedes aegypti and Ae. albopictus are forest mosquitoes. In their original habitat they breed in tree-holes, rock holes, fruit husks and other small collections of water. In the peridomestic environment they exploit man-made articles that substitute for these breeding sites. In the modern urban environment the abundance of such articles is the key factor in the abundance of these species and of the burgeoning problem of dengue, chikungunya and other viral infections that they transmit. Modern transportation technology has encouraged widespread commerce in items that can be infested; classic examples are used tires, live plants, and exotic fishes. Accelerating global trade in such items will increase the probability of introduction of such species into new regions. The advent of tens of millions of tightly packed, locked shipping containers (Fig. 8), the onus on speed in their handling and transportation, and above all their delivery unopened to their ultimate destination, have made conventional inspection in harbour redundant (Reiter, 2010a). In addition, the exponential increase in cheap air travel and transport has facilitated the movement of human and animal pathogens. In the past three decades, this mobility has sparked outbreaks of diseases such as dengue and chikungunya in many places around the world. Recent events include epidemics of chikungunya in La Reunion Island and northern Italy and of dengue in the Cape Verde Islands. Spectacular examples of other exotic pathogens, such as the explosive panzootic of West Nile virus in the New World are here to remind us the vital importance of a better knowledge and good understanding of the fine interactions 
between pathogens, mosquitoes and environmental changes, and the need to clearly admit and evaluate our role and responsibility in those phenomenons.

\section{Acknowledgment}

We would like to thank Jean Mouchet for his contribution in the revision of the manuscript. We are also grateful to Paul Reiter for many helpful suggestions.

\section{References}

Aranda, C.; Eritja, R. \& Roiz, D. (2006). First record and establishment of the mosquito Aedes albopictus in Spain. Medical Veterinary Entomology, Vol.20, No.1, pp. 150-152

Belkin, J.N. (1962). The mosquitoes of the South Pacific (Diptera: Culicidae). University of California Press, Berkeley, USA

Belton, P. \& Belton, O.C. (1990). Aedes togoi comes aboard. Journal of the American Mosquito Control Association, Vol.6, No.2, pp. 328-329

Besansky, N.J. (1999). Complexities in the analysis of cryptic taxa within the genus Anopheles. Parassitologia, Vol.41, pp. 97-100

Blanford, S.; Chan, B.H., Jenkins, N., Sim, D., Turner, R.J., Read, A.F. \& Thomas, M.B. (2005). Fungal pathogen reduces potential for malaria transmission. Science, Vol.308, No.5728, pp. 1638-1641

Boëte, C. (2006). Genetically modified mosquitoes for malaria control. Eurekah/Landes Bioscience, Georgetown, USA

Bradshaw, W.E. \& Holzapfel, C.M. (2001). Genetic shift in photoperiodic response correlated with global warming. Proceedings of the National Academy of Sciences, Vol.98, No.25, pp. 14509-14511

Bruce-Chwatt, L.J. (1980). Essential malariology. William Heinemann Med Books Ltd, London, UK

Buck, A. (1991). Filariasis, In: Strickland, T. G., Hunter's Tropical Medicine, 7th Edition. W.B. Saunders Company, Baltimore, USA

Calder, L. \& Laird, M. (1994). Mosquito travelers, arbovirus vectors and the used tire trade. Travel Medicine International, Vol.12, pp. 3-12

Carlson, J.C.; Dyer, L.A., Omlin, F.X. \& Beier, J.C. (2009). Diversity cascades and malaria vectors. Journal of Medical Entomology, Vol.46, No.3, pp. 460-464

Carvalho-Pinto, C.J. \& Lourenço-de-Oliveira, R. (2004). Isoenzimatic analysis of four Anopheles (Kerteszia) cruzii (Diptera: Culicidae) populations of Brazil. Memórias do Instituto Oswaldo Cruz, Vol.99, No.5, pp. 471-475

Chanda, E.; Masaninga, F., Coleman, M., Sikaala, C., Katebe, C., Macdonald, M., Baboo, K.S., Govere, J. \& Manga, L. (2008). Integrated vector management: the Zambian experience. Malaria Journal, Vol.7, p. 164

Coetzee, M.; Estrada-Franco, J.G., Wunderlich, C.A. \& Hunt, R.H. (1999). Cytogenetic evidence for a species complex within Anopheles pseudopunctipennis theobald (Diptera: Culicidae). American Journal of Tropical Medicine \& Hygiene, Vol.60, No.4, pp. $649-653$

Coosemans, M.; Thuan, L.K., Socheat, D., Phompida, S., Baimai, V., Manguin, S., Harbach, R.E. \& Hemingway, J. (2006). Monitoring insecticide resistance and mapping 
malaria vectors in Southeast Asia: a prerequisite for sustainable malaria vector control. INCO report, IC4-CT-2002-10041, 202 p

Daehler, C.C. (2001). Two ways to be an invader, but one is more suitable for ecology. Bulletin of the Ecological Society of America, Vol.81, pp. 101-102

Dalla Pozza, G. \& Majori, G. (1992). First record of Aedes albopictus establishment in Italy. Journal of the American Mosquito Control Association, Vol.8, No.3, pp. 318-320

Diallo, M.; Laganier, R. \& Nangouma, A. (2010). First record of Ae. albopictus (Skuse 1894), in Central African Republic. Tropical Medicine \& International Health, Vol.15, No.10, pp. 1185-1189

Dine, D.L.V. (1904). Mosquitoes in Hawaii. Bulletin of the Hawaii Agricultural Experimental Station, Vol.6, p. 30

Effler, P.V.; Pang, L., Kitsutani, P., Vorndam, V., Nakata, M., Ayers, T., Elm, J., Tom, T., Reiter, P., Rigau-Perez, J.G., Hayes, J.M., Mills, K., Napier, M., Clark, G.G. \& Gubler, D.J. (2005). Dengue fever, Hawaii, 2001-2002. Emerging Infectious Diseases, Vol.11, No.5, pp. 742-749

Fang, J. (2010). Ecology: A world without mosquitoes. Nature, Vol.466, No.7305, pp. 432-434

Foley, D.H.; Rueda, L.M. \& Wilkerson, R.C. (2007). Insight into global mosquito biogeography from country species records. Journal of Medical Entomology, Vol.44, No.4, pp. 554-567

Fonseca, D.M.; LaPointe, D.A. \& Fleischer, R.C. (2000). Bottlenecks and multiple introductions: population genetics of the vector of avian malaria in Hawaii. Molecular Ecology, Vol.9, No.11, pp. 1803-1814

Fonseca, D.M.; Smith, J.L., Wilkerson, R.C. \& Fleischer, R.C. (2006). Pathways of expansion and multiple introductions illustrated by large genetic differentiation among worldwide populations of the southern house mosquito. American Journal of Tropical Medicine E Hygiene, Vol.74, No.2, pp. 284-289

Fonseca, D.M.; Widdel, A.K., Hutchinson, M., Spichiger, S.E. \& Kramer, L.D. (2010). Finescale spatial and temporal population genetics of Aedes japonicus, a new US mosquito, reveal multiple introductions. Molecular Ecology, Vol.19, No.8, pp. 15591572

Fontenille, D. \& Toto, J.C. (2001). Aedes (Stegomyia) albopictus (Skuse), a potential new Dengue vector in southern Cameroon. Emerging Infectious Diseases, Vol.7, No.6, pp. 1066-1067

Forattini, O.P. (1986). Identification of Aedes (Stegomyia) albopictus (Skuse) in Brazil. Revista de Saúde Pública, Vol.20, No.3, pp. 244-245

Garros, C.; Van Nguyen, C., Trung, H.D., Van Bortel, W., Coosemans, M. \& Manguin, S. (2008). Distribution of Anopheles in Vietnam, with particular attention to malaria vectors of the Anopheles minimus complex. Malaria Journal, Vol.7, p. 11

Gaston, K.J. \& Hudson, E. (1994). Regional patterns of diversity and estimates of global insect species richness. Biodiversity and Conservation, Vol.3, pp. 493-500

Gratz, N.G. (2004). Critical review of the vector status of Aedes albopictus. Medical $\mathcal{E}$ Veterinary Entomology, Vol.18, No.3, pp. 215-227

Grevstad, F.S. (1999). Experimental invasions using biological control introductions: the influence of release size on the chance of population establishment. Biological Invasions, Vol.1, pp. 313-323 
Gubler, D.J. \& Clark, G.G. (1995). Dengue/dengue hemorrhagic fever: the emergence of a global health problem. Emerging Infectious Diseases, Vol.1, No.2, pp. 55-57

Gubler, D.J. (2003). Aedes albopictus in Africa. Lancet Infectious Diseases, Vol.3, No.12, pp. 751752

Guimerà, R.; Mossa, S., Turtschi, A. \& Amaral, L.A. (2005). The worldwide air transportation network: Anomalous centrality, community structure, and cities' global roles. Proceedings of the National Academy of Sciences, Vol.102, No.22, pp. 7794-7799

Harbach, R.E. (2004). The classification of genus Anopheles (Diptera: Culicidae): a working hypothesis of phylogenetic relationships. Bulletin of Entomological Research, Vol.94, pp. 537-553

Hawley, W.A.; Reiter, P., Copeland, R.S., Pumpuni, C.B. \& Craig, G.B., Jr. (1987). Aedes albopictus in North America: probable introduction in used tires from northern Asia. Science, Vol.236, No.4805, pp. 1114-1116

Hay, S.I.; Guerra, C.A., Tatem, A.J., Atkinson, P.M. \& Snow, R.W. (2005). Urbanization, malaria transmission and disease burden in Africa. Nature Reviews Microbiology, Vol.3, No.1, pp. 81-90

Hay, S.I.; Sinka, M.E., Okara, R.M., Kabaria, C.W., Mbithi, P.M., Tago, C.C., Benz, D., Gething, P.W., Howes, R.E., Patil, A.P., Temperley, W.H., Bangs, M.J., Chareonviriyaphap, T., Elyazar, I.R., Harbach, R.E., Hemingway, J., Manguin, S., Mbogo, C.M., Rubio-Palis, Y. \& Godfray, H.C. (2010). Developing global maps of the dominant Anopheles vectors of human malaria. PLoS Medicine, Vol.7, No.2, p. e1000209

Hemingway, J.; Penilla, R.P., Rodriguez, A.D., James, B.M., Edge, W., Rogers, H. \& Rodriguez, M.H. (1997). Resistance management strategies in malaria vector mosquito control. A large-scale field trial in Southern Mexico. Pesticide Science, Vol.51, pp. 375-382

Hobbs, J.H.; Hughes, E.A. \& Eichold, B.H., 2nd. (1991). Replacement of Aedes aegypti by Aedes albopictus in Mobile, Alabama. Journal of the American Mosquito Control Association, Vol.7, No.3, pp. 488-489

Hughes, T.H.; Irwin, P.M., Kaufman, A., Sage, H., Pagac, B.B., Jr. \& Paskewitz, S.M. (2008). First records of Aedes japonicus japonicus in Wisconsin. Journal of the American Mosquito Control Association, Vol.24, No.4, pp. 583-584

Izri, A.; Bitam, I. \& Charrel, R.N. (2010). First entomological documentation of Aedes (Stegomyia) albopictus (Skuse, 1984) in Algeria. Clinical Microbiology and Infection, DOI: $10.1111 / \mathrm{j} .1469-0691.2010 .03443 . x$

Juliano, S.A. \& Lounibos, L.P. (2005). Ecology of invasive mosquitoes: effects on resident species and on human health. Ecology Letters, Vol.8, No.5, pp. 558-574

Julvez, J.; Mouchet, J. \& Ragavoodoo, C. (1990). [Historical epidemiology of malaria in the archipelago of the Mascarenes (Indian Ocean)]. Annales de la Société belge de Médecine Tropicale, Vol.70, No.4, pp. 249-261

Keesing, F.; Belden, L.K., Daszak, P., Dobson, A., Harvell, C.D., Holt, R.D., Hudson, P., Jolles, A., Jones, K.E., Mitchell, C.E., Myers, S.S., Bogich, T. \& Ostfeld, R.S. (2010). Impacts of biodiversity on the emergence and transmission of infectious diseases. Nature, Vol.468, No.7324, pp. 647-652 
Killeen, G.F.; Fillinger, U., Kiche, I., Gouagna, L.C. \& Knols, B.G. (2002). Eradication of Anopheles gambiae from Brazil: lessons for malaria control in Africa? Lancet Infectious Diseases, Vol.2, No.10, pp. 618-627

Kilpatrick, A.M.; Gluzberg, Y., Burgett, J. \& Daszak, P. (2004). Threat of West Nile virus to Hawaii. Ecohealth, Vol.1, pp. 205-209

Krzywinski, J.; Li, C., Morris, M., Conn, J.E., Lima, J.B., Povoa, M.M. \& Wilkerson, R.C. (2011). Analysis of the evolutionary forces shaping mitochondrial genomes of a Neotropical malaria vector complex. Molecular Phylogenetics and Evolution, Vol.58, No.3, pp. 469-477

Lambrechts, L.; Scott, T.W. \& Gubler, D.J. (2010). Consequences of the expanding global distribution of Aedes albopictus for dengue virus transmission. PLoS Neglected Tropical Diseases, Vol.4, No.5, p. e646

Lane, R.P. \& Crosskey, R.W. (1993). Medical Insects and Arachnids, British Museum Edition. Chapman \& Hall, London, UK

Larish, L.B. \& Savage, H.M. (2005). Introduction and establishment of Aedes (Finlaya) japonicus japonicus (Theobald) on the island of Hawaii: implications for arbovirus transmission. Journal of the American Mosquito Control Association, Vol.21, No.3, pp. 318-321

Lenormand, T. \& Raymond, M. (1998). Resistance management: the stable zone strategy. Proceeding of the Royal Society of London, Vol.265, pp. 1985-1990

Livadas, G.; Mouchet, J., Gariou, J. \& Chastang, R. (1958). [Can one foresee the eradication of malaria in wooded areas of South Cameroun]. Rivista di Malariologia Vol.37, No.4-6, pp. 229-256

Lounibos, L.P. (2002). Invasions by insect vectors of human disease. Annual Review of Entomology, Vol.47, pp. 233-266

Lounibos, L.P.; O'Meara, G.F., Juliano, S.A., Nishimura, N., Escher, R.L., Reiskind, M.H., Cutwa, M. \& Greene, K. (2010). Differential Survivorship of Invasive Mosquito Species in South Florida Cemeteries: Do Site-Specific Microclimates Explain Patterns of Coexistence and Exclusion? Annals of the Entomological Society of America, Vol.103, No.5, pp. 757-770

Mak, J.W. (1987). Epidemiology of lymphatic filariasis. Ciba Foundation Symposium, Vol.127, pp. $5-14$

Manguin, S.; Carnevale, P., Mouchet, J., Coosemans, M., Julvez, J., Richard-Lenoble, D. \& Sircoulon, J. (2008a). Biodiversity of malaria in the world. John Libbey Eurotext, Paris, France

Manguin, S.; Garros, C., Dusfour, I., Harbach, R.E. \& Coosemans, M. (2008b). Bionomics, taxonomy, and distribution of the major malaria vector taxa of Anopheles subgenus Cellia in Southeast Asia: An updated review. Infection, Genetics and Evolution, Vol.8, No.4, pp. 489-503

Manguin, S.; Bangs, M.J., Pothikasikorn, J. \& Chareonviriyaphap, T. (2010). Review on global co-transmission of human Plasmodium species and Wuchereria bancrofti by Anopheles mosquitoes. Infection, Genetics and Evolution, Vol.10, No.2, pp. 159-177

Marks, E.N. (1972). Mosquitoes (Culicidae) in the changing Australian environment. Queensland Naturalist, Vol.20, pp. 101-116 
Minakawa, N.; Omukunda, E., Zhou, G., Githeko, A. \& Yan, G. (2006). Malaria vector productivity in relation to the highland environment in Kenya. American Journal of Tropical Medicine and Hygiene, Vol.75, No.3, pp. 448-453

Mouchet, J. \& Brengues, J. (1990). [Agriculture-health interface in the field of epidemiology of vector-borne diseases and the control of vectors]. Bulletin de la Société Pathologique Exotique, Vol.83, No.3, pp. 376-393

Mouchet, J.; Giacomini, T. \& Julvez, J. (1995). [Human diffusion of arthropod disease vectors throughout the world]. Cahiers Santé, Vol.5, No.5, pp. 293-298

Mouchet, J.; Manguin, S., Sircoulon, J., Laventure, S., Faye, O., Onapa, A.W., Carnevale, P., Julvez, J. \& Fontenille, D. (1998). Evolution of malaria in Africa for the past 40 years: impact of climatic and human factors. Journal of the American Mosquito Control Association, Vol.14, No.2, pp. 121-130

Mouchet, J. (1999). [Vectors and environmental factors in malaria]. Transfusion Clinique et Biologique, Vol.6, No.1, pp. 35-43

Mouchet, J. (2000). Airport malaria : a rare disease still poorly understood. Eurosurveillance, Vol.5, No.7, pp. 75-76

Mouchet, J.; Carnevale, P., Coosemans, M., Julvez, J., Manguin, S., Richard-Lenoble, D. \& Sircoulon, J. (2004). Biodiversité du paludisme dans le monde. John Libbey Eurotext, Paris, France

Narang, S.K.; Klein, T.A., Perera, O.P., Lima, J.B. \& Tang, A.T. (1993). Genetic evidence for the existence of cryptic species in the Anopheles albitarsis complex in Brazil: allozymes and mitochondrial DNA restriction fragment length polymorphisms. Biochemical Genetics, Vol.31, No.1-2, pp. 97-112

O'Meara, G.F.; Larson, V.L., Mook, D.H. \& Latham, M.D. (1989). Aedes bahamensis: its invasion of south Florida and association with Aedes aegypti. Journal of the American Mosquito Control Association, Vol.5, No.1, pp. 1-5

O'Meara, G.F.; Evans, L.F., Jr., Gettman, A.D. \& Cuda, J.P. (1995). Spread of Aedes albopictus and decline of Ae. aegypti (Diptera: Culicidae) in Florida. Journal of Medical Entomology, Vol.32, No.4, pp. 554-562

Ostfeld, R.S. \& Keesing, F. (2000). The function of biodiversity in the ecology of vector-borne zoonotic diseases. Canadian Journal of Zoology, Vol.78, No.12, pp. 2061-2078

Ostfeld, R.S. (2009). Biodiversity loss and the rise of zoonotic pathogens. Clinical Microbiology Infection, Vol.15 Suppl 1, pp. 40-43

Pages, F.; Peyrefitte, C.N., Mve, M.T., Jarjaval, F., Brisse, S., Iteman, I., Gravier, P., Tolou, H., Nkoghe, D. \& Grandadam, M. (2009). Aedes albopictus mosquito: the main vector of the 2007 Chikungunya outbreak in Gabon. PLoS One, Vol.4, No.3, p. e4691

Parmakelis, A.; Russello, M.A., Caccone, A., Marcondes, C.B., Costa, J., Forattini, O.P., Sallum, M.A., Wilkerson, R.C. \& Powell, J.R. (2008). Historical analysis of a near disaster: Anopheles gambiae in Brazil. American Journal of Tropical Medicine \& Hygiene, Vol.78, No.1, pp. 176-178

Paskewitz, S.M.; Wesson, D.M. \& Collins, F.H. (1993). The internal transcribed spacers of ribosomal DNA in five members of the Anopheles gambiae species complex. Insect Molecular Biology, Vol.2, pp. 247-257

Peterson, C.N.; Day, S., Wolfe, B.E., Ellison, A.M., Kolter, R. \& Pringle, A. (2008). A keystone predator controls bacterial diversity in the pitcher-plant (Sarracenia purpurea) microecosystem. Environmental Microbiology, Vol.10, No.9, pp. 2257-2266 
Pettit, W.J.; Whelan, P.I., McDonnell, J. \& Jacups, S.P. (2010). Efficacy of alpha-cypermethrin and lambda-cyhalothrin applications to prevent Aedes breeding in tires. Journal of the American Mosquito Control Association, Vol.26, No.4, pp. 387-397

Ramalingam, S. (1969). New record of Aedes (finlaya) togoi (Theobold) in West Malaysia. Medical Journal of Malaya, Vol.23, No.4, pp. 288-292

Read, A.F.; Lynch, P.A. \& Thomas, M.B. (2009). How to make evolution-proof insecticides for malaria control. PLoS Biology, Vol.7, No.4, p. e1000058

Reinert, J.F.; Harbach, R.E. \& Kitching, I.J. (2004). Phylogeny and classification of Aedini (Diptera: Culicidae), based on morphological characters of all life stages. Zoological Journal of the Linnean Society, Vol.142, pp. 289-368

Reiter, P. \& Sprenger, D. (1987). The used tire trade: a mechanism for the worldwide dispersal of container breeding mosquitoes. Journal of the American Mosquito Control Association, Vol.3, No.3, pp. 494-501

Reiter, P. (1998). Aedes albopictus and the world trade in used tires, 1988-1995: the shape of things to come? Journal of the American Mosquito Control Association, Vol.14, No.1, pp. 83-94

Reiter, P. (2010a). A mollusc on the leg of a beetle: Human activities and the global dispersal of vectors and vector-borne pathogens, In: Infectious Disease Movement in a Borderless World: Workshop Summary, David A. Relman, E.R.C., and Alison Mack, Rapporteurs; Forum on Microbial Threats; Institute of Medicine (Ed.), pp. 324, The National Academies Press, Washington, D.C., USA

Reiter, P. (2010b). Yellow fever and dengue: a threat to Europe? Eurosurveillance, Vol.15, No.10, p. 19509

Renault, P.; Solet, J.L., Sissoko, D., Balleydier, E., Larrieu, S., Filleul, L., Lassalle, C., Thiria, J., Rachou, E., de Valk, H., Ilef, D., Ledrans, M., Quatresous, I., Quenel, P. \& Pierre, V. (2007). A major epidemic of chikungunya virus infection on Reunion Island, France, 2005-2006. American Journal of Tropical Medicine \& Hygiene, Vol.77, No.4, pp. 727-731

Ritchie, S.A.; Rapley, L.P. \& Benjamin, S. (2010). Bacillus thuringiensis var. israelensis (Bti) provides residual control of Aedes aegypti in small containers. American Journal of Tropical Medicine \& Hygiene, Vol.82, No.6, pp. 1053-1059

Robert, V.; Rocamora, G., Julienne, S. \& Goodman, S.M. (2011). Why are anopheline mosquitoes not present in the Seychelles? Malaria Journal, Vol.10, No.1, p. 31

Rodhain, F. (1996). [Insects know no border]. Médecine et Maladies Infectieuses, Vol.26 Suppl 3, pp. 408-414

Rogers, D.J.; Randolph, S.E., Lindsay, S. \& Thomas, C. (2001). Health effects of climate change in the U.K. U.K. Department of Health, London, UK

Romi, R.; Sabatinelli, G., Savelli, L.G., Raris, M., Zago, M. \& Malatesta, R. (1997). Identification of a North American mosquito species, Aedes atropalpus (Diptera: Culicidae), in Italy. Journal of the American Mosquito Control Association, Vol.13, No.3, pp. $245-246$

Rosen, L.; Rozeboom, L.E., Reeves, W.C., Saugrain, J. \& Gubler, D.J. (1976). A field trial of competitive displacement of Aedes polynesiensis by Aedes albopictus on a Pacific atoll. American Journal of Tropical Medicine E Hygiene, Vol.25, No.6, pp. 906-913

Rozendaal, J.A. (1997). Vector control: methods for use by individuals and communities. WHO, Geneva, Switzerland 
Schaffner, F. \& Karch, S. (2000). [First report of Aedes albopictus (Skuse, 1984) in metropolitan France]. Comptes Rendus de l'Académie des Sciences - Série III - Sciences de la Vie, Vol.323, No.4, pp. 373-375

Schaffner, F.; Van Bortel, W. \& Coosemans, M. (2004). First record of Aedes (Stegomyia) albopictus in Belgium. Journal of the American Mosquito Control Association, Vol.20, No.2, pp. 201-203

Schaffner, F.; Kaufmann, C., Hegglin, D. \& Mathis, A. (2009). The invasive mosquito Aedes japonicus in Central Europe. Medical E Veterinary Entomology, Vol.23, No.4, pp. 448451

Scholte, E. \& Schaffner, F. (2007). Waiting for the tiger: Establishment and spread of the Aedes albopictus mosquito in Europe. Wageningen Academic Publishers, Wageningen, The Netherlands

Scholte, E.J.; Ng'habi, K., Kihonda, J., Takken, W., Paaijmans, K., Abdulla, S., Killeen, G.F. \& Knols, B.G. (2005). An entomopathogenic fungus for control of adult African malaria mosquitoes. Science, Vol.308, No.5728, pp. 1641-1642

Scholte, E.J.; Den Hartog, W., Braks, M., Reusken, C., Dik, M. \& Hessels, A. (2009). First report of a North American invasive mosquito species Ochlerotatus atropalpus (Coquillett) in the Netherlands, 2009. Eurosurveillance, Vol.14, No.45,

Séchan, Y.; Lardeux, F., Loncle, S., Rivière, F. \& Mouchet, J. (1993). Les arthropodes vecteurs de maladies et agents de nuisances en Polynésie Française. Atlas de la Polynésie Française, Orstom, France

Shousha, A.T. (1948). Species-eradication: The eradication of Anopheles gambiae from Upper Egypt, 1942-1945. Bulletin of the World Health Organization, Vol.1, No.2, pp. 309-352

Singh, O.P.; Nanda, N., Dev, V., Bali, P., Sohail, M., Mehrunnisa, A., Adak, T. \& Dash, A.P. (2010). Molecular evidence of misidentification of Anopheles minimus as Anopheles fluviatilis in Assam (India). Acta Tropica, Vol.113, No.3, pp. 241-244

Sinka, M.E.; Bangs, M.J., Manguin, S., Coetzee, M., Mbogo, C.M., Hemingway, J., Patil, A.P., Temperley, W.H., Gething, P.W., Kabaria, C.W., Okara, R.M., Van Boeckel, T., Godfray, H.C., Harbach, R.E. \& Hay, S.I. (2010a). The dominant Anopheles vectors of human malaria in Africa, Europe and the Middle East: occurrence data, distribution maps and bionomic précis. Parasites $\mathcal{E}$ Vectors, Vol.3, p. 117

Sinka, M.E.; Rubio-Palis, Y., Manguin, S., Patil, A.P., Temperley, W.H., Gething, P.W., Van Boeckel, T., Kabaria, C.W., Harbach, R.E. \& Hay, S.I. (2010b). The dominant Anopheles vectors of human malaria in the Americas: occurrence data, distribution maps and bionomic précis. Parasites \& Vectors, Vol.3, p. 72

Sinka, M.E.; Bangs, M.J., Manguin, S., Chareonviriyaphap, T., Patil, A.P., Temperley, W.H., Gething, P.W., Elyazar, I.R., Kabaria, C.W., Harbach, R.E. \& Hay, S.I. (2011). The dominant Anopheles vectors of human malaria in the Asia-Pacific region: occurrence data, distribution maps and bionomic précis. Parasites $\mathcal{E}$ Vectors, Vol.4, No.1, p. 89

Skovmand, O.; Ouedraogo, T.D., Sanogo, E., Samuelsen, H., Toe, L.P. \& Baldet, T. (2009). Impact of slow-release Bacillus sphaericus granules on mosquito populations followed in a tropical urban environment. Journal of Medical Entomology, Vol.46, No.1, pp. 67-76

Smith, J.L. \& Fonseca, D.M. (2004). Rapid assays for identification of members of the Culex (Culex) pipiens complex, their hybrids, and other sibling species (Diptera: culicidae). American Journal of Tropical Medicine E Hygiene, Vol.70, No.4, pp. 339-345 
Soper, F.L. \& Wilson, D.B. (1943). Anopheles gambiae in Brasil, 1930-1940. (New York, USA, The Rockefeller Foundation), p. 262

Tabachnick, W.J. \& Walter, J. (1991). Evolutionary genetics of arthropod-borne diseases. The yellow fever mosquito. American Entomologist, Vol.37, pp. 14-26

Tatem, A.J.; Hay, S.I. \& Rogers, D.J. (2006a). Global traffic and disease vector dispersal. Proceedings of National Academy of Sciences of the USA, Vol.103, No.16, pp. 6242-6247

Tatem, A.J.; Rogers, D.J. \& Hay, S.I. (2006b). Global transport networks and infectious disease spread. Advances in Parasitology, Vol.62, pp. 293-343

Tatem, A.J. (2009). The worldwide airline network and the dispersal of exotic species: 20072010. Ecography (Cop.), Vol.32, No.1, pp. 94-102

Thien, L.B. (1969). Mosquito pollination of Habenaria obtusata (Orchidaceae). American Journal of Botany, Vol.56, No.2, pp. 232-237

Toto, J.C.; Abaga, S., Carnevale, P. \& Simard, F. (2003). First report of the oriental mosquito Aedes albopictus on the West African island of Bioko, Equatorial Guinea. Medical \& Veterinary Entomology, Vol.17, No.3, pp. 343-346

Van Bortel, W.; Harbach, R.E., Trung, H.D., Roelants, P., Backeljau, T. \& Coosemans, M. (2001). Confirmation of Anopheles varuna in vietnam, previously misidentified and mistargeted as the malaria vector Anopheles minimus. American Journal of Tropical Medicine \& Hygiene, Vol.65, No.6, pp. 729-732

Van Riper, C.; Van Riper, S.G., Goff, M.L. \& Laird, M. (1986). The epizootiology and ecological significance of malaria in Hawaiian land birds. Ecological Monographs, Vol.56, pp. 327-344

Vinagradova, E.B. (2000). Culex pipiens pipiens mosquitoes: taxonomy, distribution, physiology, genetics, applied importance and control. Pensoft, Moscow, Russia

Weinstein, P.; Laird, M. \& Browne, G. (1997). Exotic and endemic mosquitoes in New Zealand as potential arbovirus vectors (Wellington, UK, Ministry of Health), p. 16

WHO. (1989). Geographical distribution of arthropod-borne disease and their principal vectors. In: WHO/VBC/89.967, WHO (Ed.), Geneva, Switzerland

Wickson, F. (2010). Mosquitoes: just how much biodiversity does humanity need? Nature, Vol.466, No.7310, p. 1041 


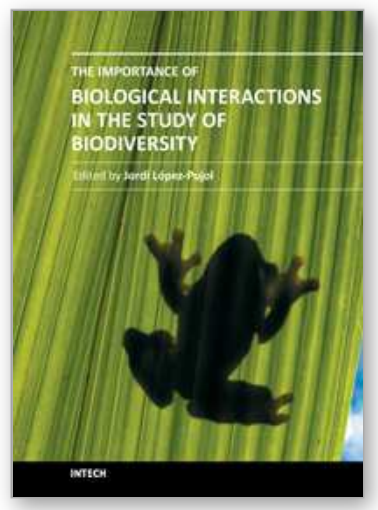

\section{The Importance of Biological Interactions in the Study of Biodiversity}

Edited by Dr. Jordi LÃ $\tilde{\beta}^{3}$ ez-Pujol

ISBN 978-953-307-751-2

Hard cover, 390 pages

Publisher InTech

Published online 22, September, 2011

Published in print edition September, 2011

The term biodiversity defines not only all the variety of life in the Earth but also their complex interactions. Under the current scenario of biodiversity loss, and in order to preserve it, it is essential to achieve a deep understanding on all the aspects related to the biological interactions, including their functioning and significance. This volume contains several contributions (nineteen in total) that illustrate the state of the art of the academic research in the field of biological interactions in its widest sense; that is, not only the interactions between living organisms are considered, but also those between living organisms and abiotic elements of the environment as well as those between living organisms and the humans.

\section{How to reference}

In order to correctly reference this scholarly work, feel free to copy and paste the following:

Sylvie Manguin and Christophe Boëte (2011). Global Impact of Mosquito Biodiversity, Human Vector-Borne Diseases and Environmental Change, The Importance of Biological Interactions in the Study of Biodiversity, Dr. Jordi LÃpez-Pujol (Ed.), ISBN: 978-953-307-751-2, InTech, Available from:

http://www.intechopen.com/books/the-importance-of-biological-interactions-in-the-study-of-biodiversity/globalimpact-of-mosquito-biodiversity-human-vector-borne-diseases-and-environmental-change

\section{INTECH}

open science | open minds

\section{InTech Europe}

University Campus STeP Ri

Slavka Krautzeka 83/A

51000 Rijeka, Croatia

Phone: +385 (51) 770447

Fax: +385 (51) 686166

www.intechopen.com

\section{InTech China}

Unit 405, Office Block, Hotel Equatorial Shanghai

No.65, Yan An Road (West), Shanghai, 200040, China

中国上海市延安西路65号上海国际贵都大饭店办公楼 405 单元

Phone: +86-21-62489820

Fax: $+86-21-62489821$ 
(C) 2011 The Author(s). Licensee IntechOpen. This chapter is distributed under the terms of the Creative Commons Attribution-NonCommercialShareAlike-3.0 License, which permits use, distribution and reproduction for non-commercial purposes, provided the original is properly cited and derivative works building on this content are distributed under the same license. 